\title{
EVOLVING SCENARIOS OF ORGANIC MATTER CONCENTRATION IN ALTO TIETÉ BASIN BY MATHEMATICAL MODELING
}

\author{
MONTOVANI, C. P.* \& POLETTI, E. C. C. \\ College of Technology, State University of Campinas, Paschoal Marmo Street, 1888, Jardim Nova \\ Itália, Limeira/SP, Brazil. \\ ${ }^{*}$ Corresponding author: camilamontovani@yahoo.com.br
}

\begin{abstract}
Montovani, C. P.* \& Poletti, E. C. C. (2015). Evolving scenarios of organic matter concentration in alto Tietê basin by mathematical modeling. braz. J. Aquat. Sci. Technol. 19(2). elSSN 1983-9057. DOI: 10.14210/bjast.v19n2. Water bodies have been suffering with the pollution caused by the inappropriate disposal of domestic and industrial sewage. The problem is related, mainly, to the organic matter and scenarios without appropriate treatments, becoming a major problem for the society health and for the own environment. Thereby, the present study evaluated the evolutionary framework of organic matter concentration in an aquatic system, via mathematical modeling, using a model based on a system of subtraction equations and presented it using computer simulations. The study case used in this research was, therefore, the situation of the Tietê River and its values of biochemical oxygen demand. The results are expected to promote relevant discussions and understandings about the pollution of this River, by showing the existence of dumping and the high levels of pollution along a stretch of it.
\end{abstract}

Key words: BDO, Tietê River, Mathematical modeling.

\section{INTRODUCTION}

Pollution of water bodies is a consequence of social and economic development of society, which interferes in the aquatic and human population's health and life quality. The impacts from pollution have become a major problem for the management of the environment. Among them, the ones caused by organic matter intake, generally related to agricultural potential, industrial and other anthropogenic activities, are highlighted.

The organic matter is introduced into water systems through punctual or diffusive influx. The substances that enter the environment go through one decomposition process consuming oxygen and releasing nutrients used by the algae. This phenomenon corroborates to increase the eutrophication and the fish deaths due to low levels of dissolved oxygen. In the case of anaerobic decomposition, the environment becomes acid and releases toxic gases, causing damages to aquatic life.

High levels of organic matter in the water affect negatively the quality of this resource and change its physical, chemical and biological structure, causing impact in the use of multiple uses of water. For public water supply, it is necessary that minimum toxicological conditions of water quality are guaranteed. In terms of the organic matter, BOD, the Biochemical Oxygen Demand, is a major indicator of water bodies' pollution. It is a measure of the amount of oxygen (dissolved in water) used by aerobic organisms (such as bacteria, fungi and yeasts) in a decomposition process of or- ganic matter at a given temperature in a given period of time (Quevedo, 2009).

According to CONAMA, the national environmental council of Brazil, the maximum amount permissible oxygen depends on the River classification. For class two water bodies, it is suggested $5 \mathrm{mg} \mathrm{L}-1$ and, for the class three, $10 \mathrm{mg} \mathrm{L}-1$ (these values are expressed in milligrams of oxygen consumed per liter of sample, for five days incubation at $\left.20^{\circ} \mathrm{C}\right)($ CONAMA, 2005).

Located in the state of São Paulo, the Tietê River is considered one of the most polluted rivers in the world. It is one of the major state rivers and its degrading scenario is established due to the inefficiency of the wastewater treatment, to the high population density of the region and the large number of operating industries in the city (Rocha et al., 2009).

To analyze and understand the scenario that is established in the Tietê River, this study considered BOD measures. Thereby, the purpose of this study was to present and to discuss the evolutionary framework of the organic matter's concentration in the Tietê River with high levels of intake regions that have a large amount of industries and people.

\section{CHARACTERIZATION OF UGRHI 6 AND TIETÊ RIVER}

The State of São Paulo is divided in twenty two Units of Water Resources' Management (UGRHIs) and each UGRHI is classified into agriculture, conservation, 
industrializing and industrial, Figure 1.

The Tietê River basin is divided into three subbasins: Alto Tietê, Médio Tietê e Baixo Tietê. The subbasin Alto Tietê belongs to UGRHI 6, Figure 1, and is divided into six sub-regions: Tietê/Cabeceiras, Billings/ Tamanduateí, Penha/Pinheiros, Cotia/Guarapiranga, Juqueri/Cantareira e Pinheiros/Pirapora.

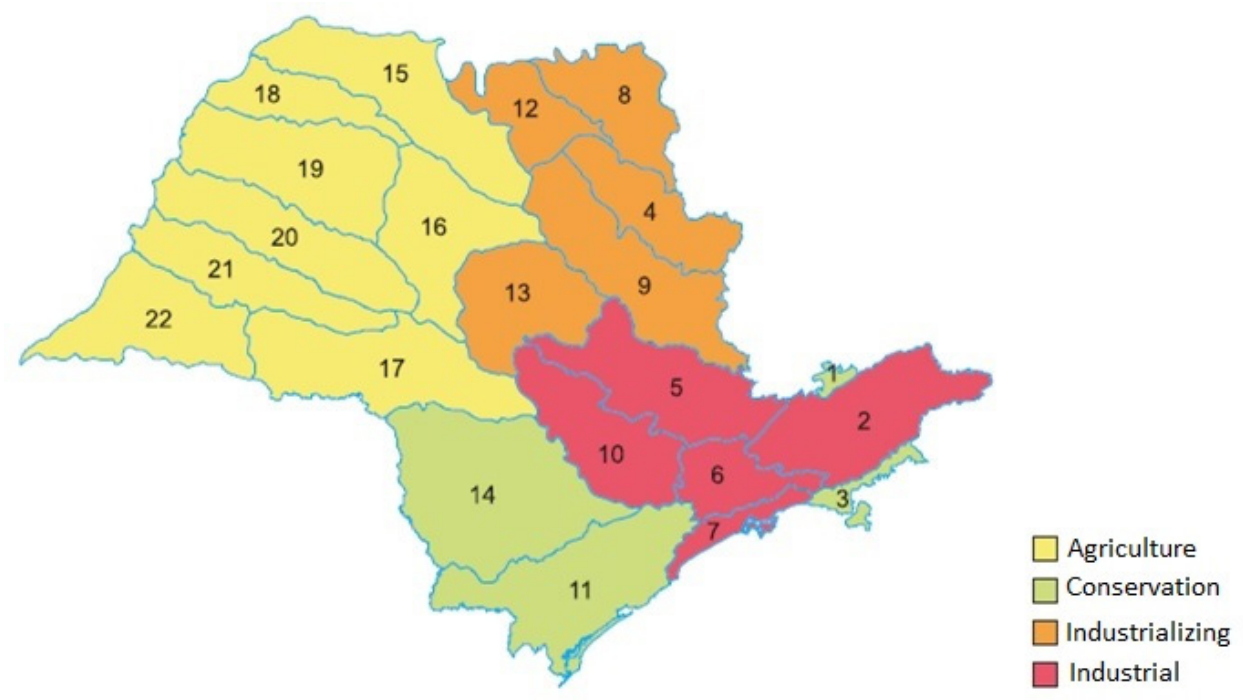

Figure 1 - Classification and location of UGRHI 6. Source: CETESB, 2012.

The Tietê River fountain is located on the frontier between Salesópolis/SP and Paraibuna/SP and follows up to the Pirapora reservoir in Pirapora do Bom Jesus/ SP, Figure 2, covering a stretch of $230 \mathrm{~km}$ (CETESB, 2008; Plan of the Alto Tietê River Basin, 2009; Rocha et al., 2009; CETESB, 2012).
This is an industrial UGRHI and it's also the most populous in the state of São Paulo, with 20.386.396 inhabitants and composed by 34 municipalities. The drained area of $5.868 \mathrm{~km}^{2}$ is considered the fourth smallest area drained from the 22's UGRHI state (CETESB, 2013).

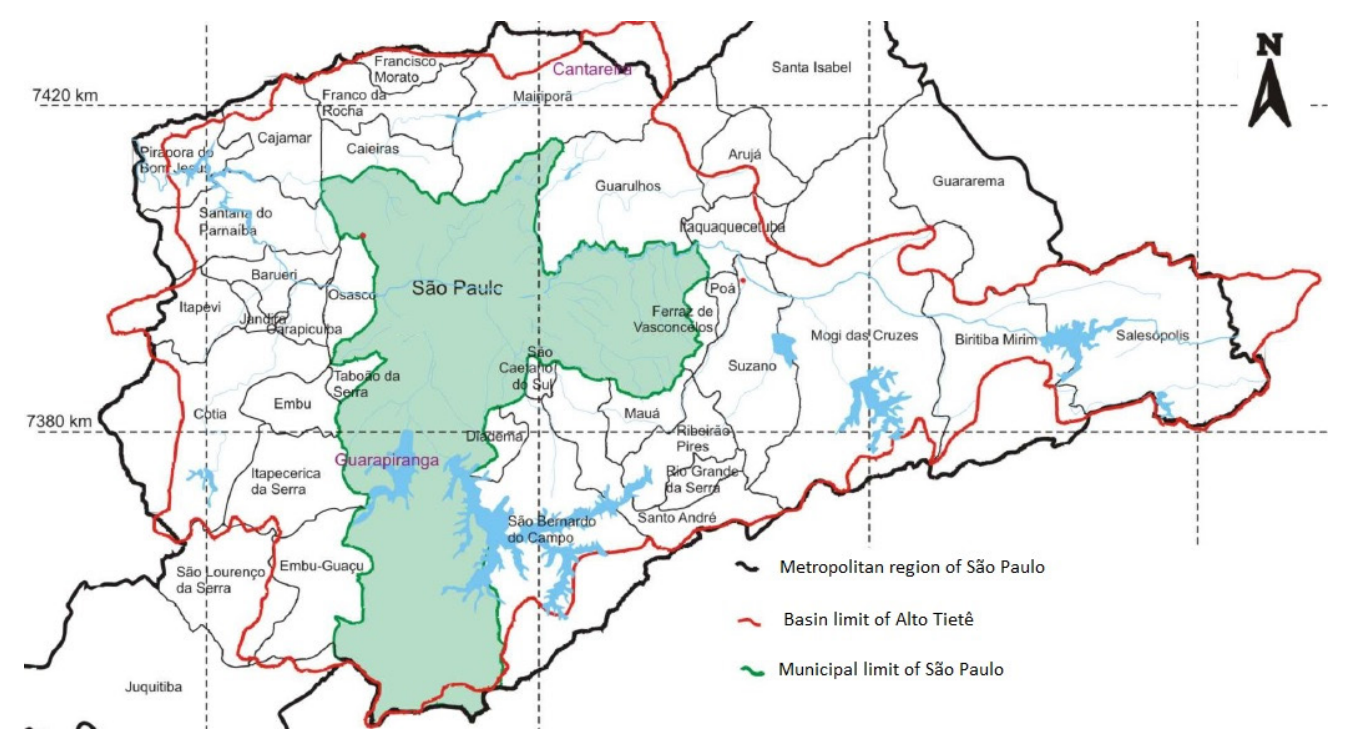

Figure 2 - Alto Tietê basin. Source: adapted from Martins, 2008.

Approximately $88 \%$ of domestic sewage is collected in the area, but only $54 \%$ is treated. The remaining charge is $633.253 \mathrm{~kg}$ DBO day- 1 and the Municipalities of Urban Population's Collection Rate and Treatability of Sewers, ICTEM, is 5.23 (CETESB, 2013).
Between the cities that compose the UGRHI 6, São Paulo is the most populous, with 11.715 .608 inhabitants. The city has $97 \%$ of the sewage collected and treats $75 \%$ of it. Their remaining pollution load is $279.324 \mathrm{~kg}$ DBO day-1 and shows an ICTEM rate equal to 6.71 (CETESB, 2013). 
There are several reservoirs supplied by the waters of the Tietê River that are used for public supply of their municipalities (Rocha et al., 2009; CETESB, 2012).

Throughout UGRHI 6 there are eight sampling points of the waters of the River Tietê, in which the determination of the BOD parameter is set up (TIET 02050, TIET 02090, TIET 03120, TIET 03130, TIET 04150, TIET 04170, TIET 04180 e TIET 04200).

In terms of water quality classification, TIET 02050 and TIET 02090 points are classified as class two, the TIET 03120 and TIET 03130 points are class three and the other points are classified as class four whose multiple uses are intended for navigation and landscape harmony (CONAMA, 2005; CETESB, 2012).

The sub-basin of the Alto Tietê is extremely important for the state of São Paulo, because it is used for public supply of many towns. However, in most of the points, the water quality does not meet the quality standards, mainly because of the inefficient sewage treatment system that leads to changes in the physical and chemical characteristics of water (Rocha et al., 2009).

\section{THE MODEL}

The mathematical model used is based on a system of subtraction equations and provides a mathematical idealization of the evolving behavior of the concentration of pollutants in an aquatic environment (Edelstein-Keshet, 1988).

Used by the EPA, United States Environmental Protection Agency, this model plays a role in assisting the predictive study reviews in the evolving behavior of the concentration of a component and can give base to discussions of control strategies and rehabilitation of water sources in order to preserve resources (Inforzato, 2008; Montovani \& Poletti, 2012).

Mathematically, the general equation is given by

$$
C^{k+1}=C^{k}-\frac{F}{V} V-d C^{k}+q^{k}
$$

where:

- $d$ represents the degradation rate $\left(\right.$ month $\left.^{-1}\right)$;

- $V$ represents the river volume $\left(\mathrm{m}^{3}\right)$;

- $F$ indicates the flow of the river $\left(\mathrm{m} \mathrm{s}^{-1}\right)$;

- $C^{k+1}$ indicates the amount of pollution in future time $(k+1)$;

- $C^{k}$ indicates the amount of pollutant in the present tense $(k)$, and finally

- $q$ represents the contribution of pollutant released $\left(\mathrm{kg} \mathrm{DBO} \mathrm{s}^{-1}\right)$.

The Tietê River in the Alto Tietê basin runs 230 $\mathrm{km}$, has an average width of $50 \mathrm{~m}$ and average depth of $4.35 \mathrm{~m}$, resulting in a volume of approximately $50.025 .000 \mathrm{~m}^{3}$ (Rocca, 1995; Plan of the Alto Tietê River Basin, 2009; Ministry of Transport, 2013).

For the modeling, the region of UGRHI 6 was divided into nine compartments homeomorphic to rectangles, according to the classification of water along the river extension and its sources. Thus, each compartment covers, possibly, more than one municipality and has specific characteristics of distance, drainage area, flow and supply as presented in Table 1 .

Table 1 - Characteristics of the UGRHI 6 per compartment.

\begin{tabular}{|c|c|c|c|c|c|c|c|}
\hline $\begin{array}{c}\text { Municipalities } \\
\text { contained in each } \\
\text { compartment } \\
\end{array}$ & Compartment & Class & Distance (m) & Area $\left(m^{2}\right)$ & Volume $\left(\mathrm{m}^{3}\right)$ & Flow $\left(\mathrm{m} \mathrm{s}^{-1}\right)$ & $\begin{array}{c}\text { Input } \\
\left(\mathrm{Kg} \mathrm{DBO} \mathrm{s}^{-1}\right)\end{array}$ \\
\hline Salesópolis & 1 & 2 & $35.000,00$ & $1.750 .000,00$ & $7.612 .500,00$ & 0,0000480 & 0,002 \\
\hline Biritiba-Mirim & 2 & 2 & $15.000,00$ & $750.000,00$ & $3.262 .500,00$ & 0,0001120 & 0,009 \\
\hline Mogi das Cruzes & 3 & 3 & $45.000,00$ & $2.250 .000,00$ & $9.787 .500,00$ & 0,0000373 & 0,158 \\
\hline $\begin{array}{l}\text { Suzano, Poá, } \\
\text { Itaquaquecetuba }\end{array}$ & 4 & 3 & $35.000,00$ & $1.750 .000,00$ & $7.612 .500,00$ & 0,0000480 & 0,280 \\
\hline Guarulhos, São Paulo & 5 & 3 & $55.000,00$ & $2.750 .000,00$ & $11.962 .500,00$ & 0,0000305 & 4,015 \\
\hline Osasco & 6 & 3 & $10.000,00$ & $500.000,00$ & $2.175 .000,00$ & 0,0001680 & 0,347 \\
\hline Carapicuíba & 7 & 4 & $5.000,00$ & $250.000,00$ & $1.087 .500,00$ & 0,0003360 & 0,196 \\
\hline $\begin{array}{l}\text { Santana do Parnaíba, } \\
\text { Barueri }\end{array}$ & 8 & 4 & $25.000,00$ & $1.250 .000,00$ & $5.437 .500,00$ & 0,0000672 & 0,206 \\
\hline Pirapora do Bom Jesus & 9 & 4 & $5.000,00$ & $250.000,00$ & $1.087 .500,00$ & 0,0003360 & 0,008 \\
\hline
\end{tabular}

Table adapted from sources: ROCHA et al., 2009; CETESB, 2012. 
Table 1 indicates the compartment, followed by the classification according to the monitoring agency's water quality, distance, area, volume, flow and input. Considering that the potential for degradation of organic matter is directly related to the health of the water body, it was considered degradation of $1 \%$ month- 1 for the compartments of class four; $5 \%$ month -1 for the compartments of class three and $15 \%$ month -1 for the compartments of class two.

The initial concentration of BOD considered was $0.002 \mathrm{~kg} \mathrm{DBO} \mathrm{s}-1$, which is the initial concentration of pollutant in the compartment one, where is located the river's fountain.

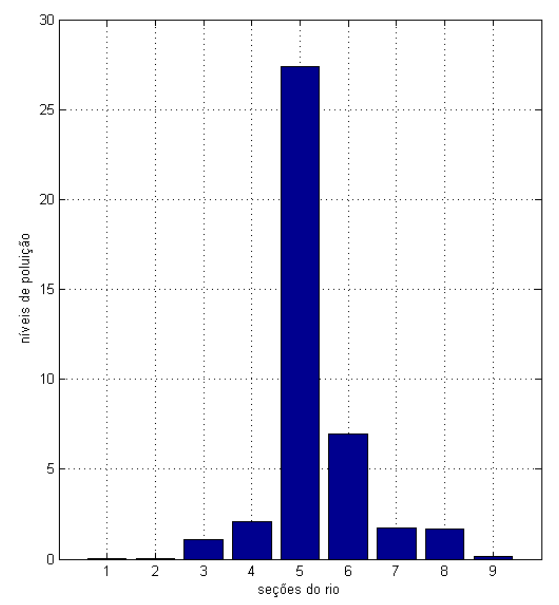

Figure 3 - 8 weeks simulation.

In this figure, there is a higher concentration of organic matter in the compartment 5 , that although it is the largest in terms of volume, is what gets higher concentrations in $\mathrm{kg}$ DBO s-1 and still presents an increasing behavior for the period considered.

According to the modeling, compartment 5 includes the cities of São Paulo and Guarulhos, where

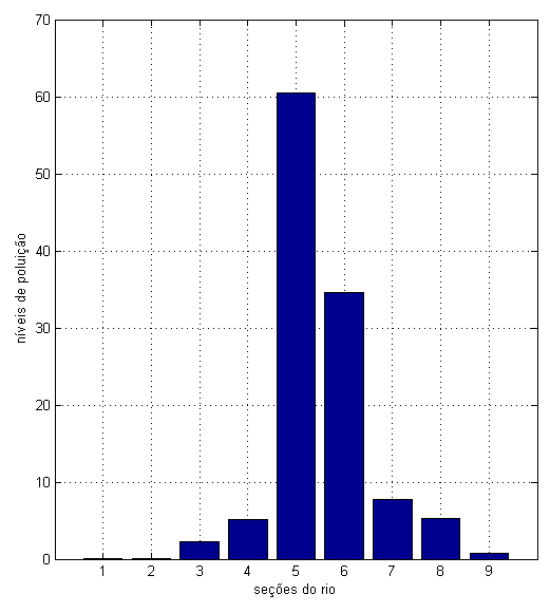

Figure 4 - 25 weeks simulation.

\section{RESULTS AND DISCUSSION}

The simulations of the evolving behavior of organic matter concentration in the Tietê River were performed in Matlab and then submitted by the following figures represented with time variation: 8, 25, 52, 104 and 1000 weeks. This time fragmentation was adopted in order to gradually evaluate the evolving phenomenon and also to analyze the time needed to reach the asymptotic behavior of the pollutant concentration in the environment.

Considering a period of 8 weeks, the simulation is presented by Figure 3:

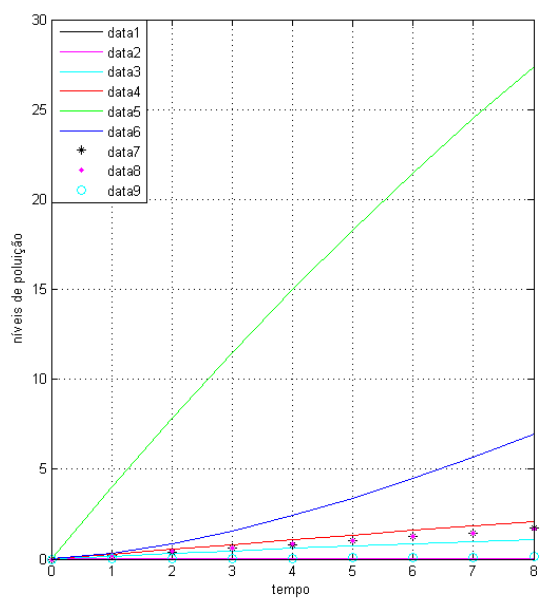

there is a large concentration of people and industries. It is found in Figure 3 that are needed, approximately, two weeks for the waters of the river, in this compartment, exceed the maximum limit of $10 \mathrm{mg} \mathrm{L}-1$ de BOD, for water bodies classified as class three.

In Figure 4, it is considered a period of 25 weeks, such as presented:

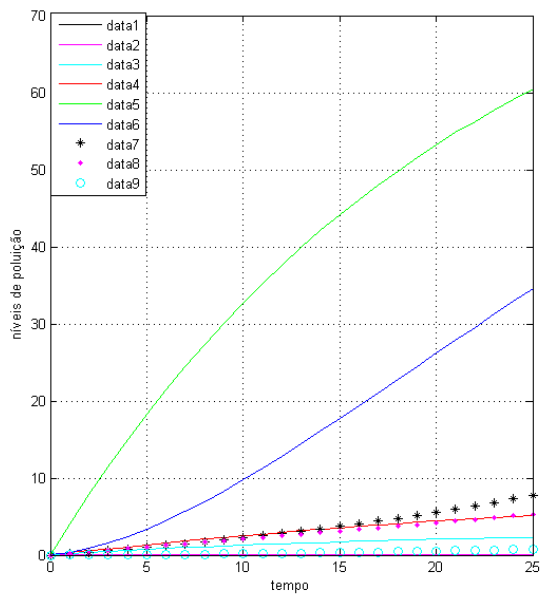


In about six months, as it can be seen on Figure 4 , there is a higher concentration of organic material in the compartments 5 and 6 , followed by significant values $\mathrm{kg}$ DBO s-1 in the compartments 3, 4, 7 and 8 .

The compartment 6 , whose concentration of organic matter already stands out in Figure 3, simulation of eight weeks, represents the city of Osasco and its waters are classified, according to the monitoring agency of the water quality in the state, as class three. It is noted that, in ten weeks, the concentration of organic matter exceeds the maximum established value,

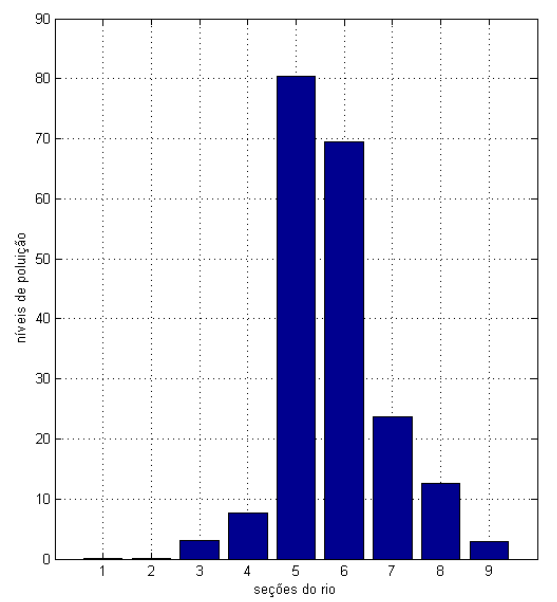

Figure 5 - 52 weeks simulation.

In Figure 5, the pollution levels in the compartments will increase progressively as a time function. Compartments 1 and 2 represent the cities of Salesópolis and Biritiba-Mirim respectively and they are classified as class two, with low levels of pollution. It is possible to verify that the other compartments

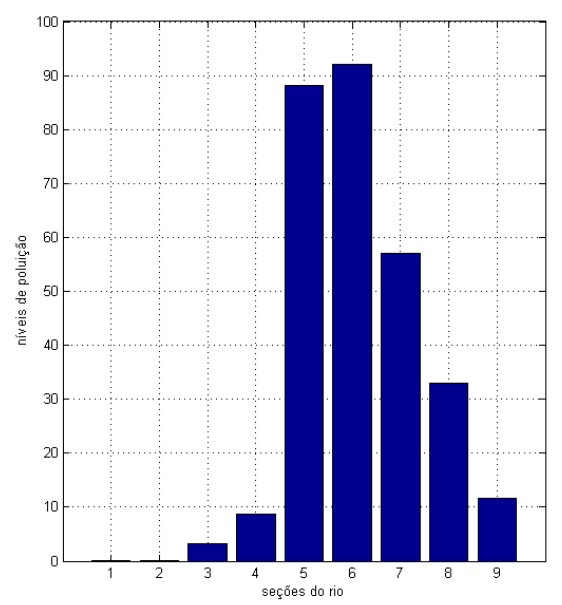

Figure 6 - 104 weeks simulation. reaching, within six months, a BOD of about $35 \mathrm{mg} \mathrm{L}-1$. The waters of the compartments 7 , which contain Carapicuíba, 8, which includes Santana do Parnaiba and Barueri, and 9, which contains Pirapora do Bom Jesus, are classified as class four. However, for this classification, there is no maximum limit due to concentration organic matter, and so the BOD level is high.

Considering a period of 52 weeks, a simulation is showed in Figure 5:

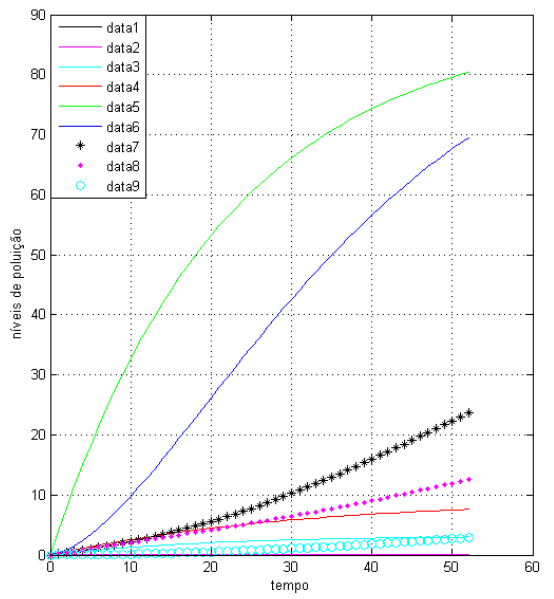

still have increasing levels of pollution. The stretches classified as class three, compartments 3 and 4 , don't exceed the stipulated maximum limit of $10 \mathrm{mg} \mathrm{L}-1$. Increasing the simulation period to 104 weeks, there is Figure 6:

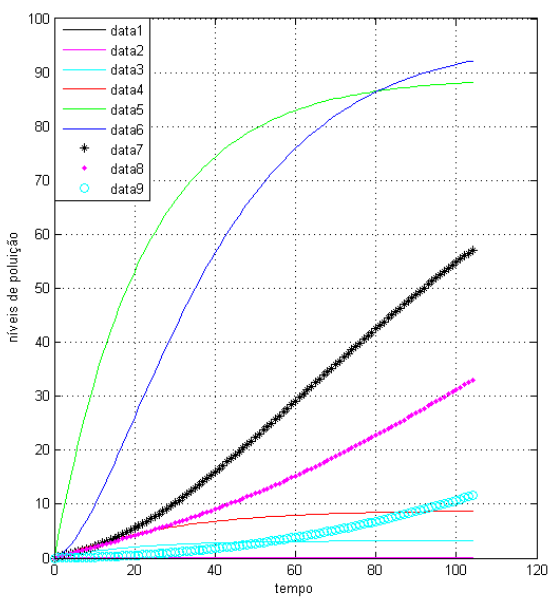


As it can be seen in Figure 6, the compartments 5 and 6 (classes three) and the compartments 7 and 8 (classes four) show the highest levels of pollution of all compartments. Moreover, it is observed that the compartments 1 and 2 (class two) and the compartments

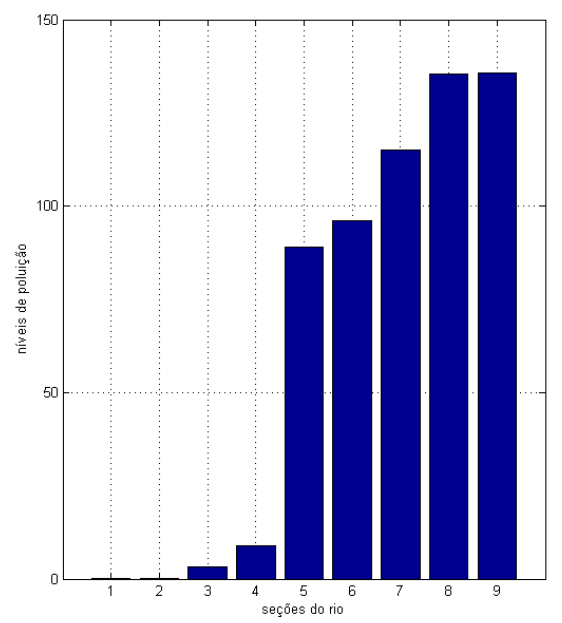

Figure 7 - 1000 weeks simulation.

In Figure 7, there is a higher concentration of organic matter in the compartments $5,6,7,8$, and 9 , indicating more affected scenarios in terms of water pollution in the cities of Guarulhos, São Paulo, Osasco, Carapicuíba, Santana do Parnaiba, Barueri and Bom Jesus de Pirapora, stretches in which the water will be classified as class three and four. It seems that some compartments are changing their behavior as a function of time, such as what is happening with compartment 9 that becomes more polluted.

\section{CONCLUSIONS}

With the extensive development of technology and the mathematical and computational tools, it was possible to generate scenarios and to observe that, over time, pollution levels progressively increased, once the supply is greater than the self-purification of the river, so pollution levels increased downstream of the point where there is the input.

With the model, it was possible to detect the progress deterioration of water quality by increasing pollutant concentrations and disqualification of selfpurification in Tietê River as it receives a large volume of untreated effluents.

The solution to reduce pollution levels is to require that municipal governments and industries do the treatment of domestic and industrial wastewater before disposing it in the Tietê River, increase supervision and impose fines in the case of illegal disposal.
3 and 4 (classes three) are stabilized, while others still show increasing levels of pollution.

The asymptotic value of all compartments is obtained at approximately 900 weeks as shows Figure 7.

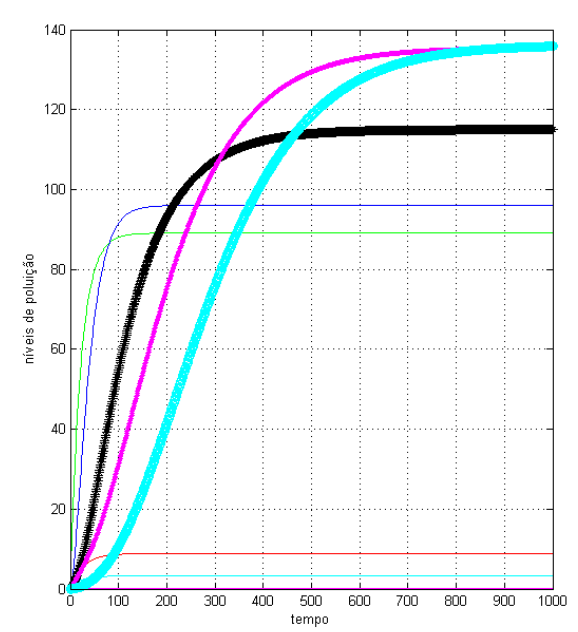

\section{REFERENCES}

CETESB. Environmental Company of the State of São Paulo. 2008. Quality of inland waters in the state of São Paulo 2008. São Paulo, Brazil. 528p. Available: <http://www.cetesb.sp.gov.br/media/ files/Agua/relatorios/rios/rel_aguas_int_2008/ relatorio_2008.zip>. Accessed in: 2013, Sep. 05.

CETESB. Environmental Company of the State of São Paulo. 2012. Quality of surface water in the state of São Paulo 2012. São Paulo, Brazil. 370p. Available: <http://www.cetesb.sp.gov.br/userfiles/ file/agua/aguas-superficiais/relatorio-aguassuperficiais-2012-substituido-em-060513.zip>. Accessed in: 2013, Aug. 28.

CONAMA. National Environmental Council. 2005. Resolution n. 357 of March 17, 2005. Brasília, DF. Available: <http://www.mma.gov.br/port/conama/ res/res05/res35705.pdf> Accessed in: 2013, may. 05.

Edelstein-Keshet L. 1988. Mathematical models in biology. $1^{\text {a }}$ Edition. México. 586p.

Inforzato, N. F. 2008. Pollutant dispersion in an airwater system: mathematical modeling, numerical approximation and computer simulation. Thesis (PhD in Applied Mathematics) - Institute of Mathematics, Statistics and Computer Graphics, State University of Campinas, Campinas. 109p. Available: <http://cutter.unicamp.br/ document/?code=vtls000441185> Accessed in: 2014, Oct. 06. 
Martins, V. T. S. 2008. Application of Pb, Sr. H and O isotopes as tracers of recharge and contamination of metropolitan aquifers: an example of the Alto Tietê basin. Thesis (PhD in Geochemistry and Géotectonique) - Institute of Geosciences, University of São Paulo. 196p. Available: <http:// www.teses.usp.br/teses/disponiveis/44/44142/ tde-19122008-084523/pt-br.php> Accessed in: 2014, Sep. 27.

Ministry of Transport. Rivers and River basin districts, 2013. Available: <http://www.mma.gov.br/port/ conama/res/res05/res35705.pdf>. Accessed in: 2014, set. 27.

Montovani, C. P.; Poletti, E. C. C. O impacto ambiental na bacia do Ribeirão do Pinhal - município de Limeira-SP: Caracterização, modelagem matemática e discussões. Biomatemática, Campinas, v. 22, p. 105-116. 2012. Available: <http://www.ime.unicamp.br/ biomat/bio22.pdf>. Accessed in: 2013, may. 05.

Plan of the Alto Tietê River Basin. Report Final. 2009, v. 1. Available: <http://www.fabhat.org.br/site/images/ docs/volume_1_pat_dez09.pdf>. Accessed in: 2014, jun. 02.
Quevedo, C. M. G. 2009. The activities of man and the evolution of phosphorus dynamics in the environment. Dissertation (Master of Public Health) - School of Public Health, University of São Paulo. 247p. Available: <http://www.teses.usp.br/teses/ disponiveis/6/6134/tde-08012010-110552/pt-br. php> Accessed in: 2014, Oct. 07.

Rocca, F. F. D. 1995. Dose estimation in individuals resulting from the liquid effluent release by IPEN. Dissertation (Master of Science) - Institute of Energy and Nuclear Research, linked to the University of São Paulo, São Paulo. 113p. Available: <http://pelicano.ipen.br/PosG30/TextoCompleto/ Fatima\%20Fernandes\%20Della\%20Rocca_M.pdf $>$ Accessed in: 2014, set. 10.

Rocha, P. S.; Luvizotto, G. L.; Kosmehl, T.; Böttcher, M; Storch, V.; Braunbeck, T. \& Hollert, H. 2009. Sediment genotoxicity in the Tietê River (São Paulo, Brazil): In vitrocomet assay versus in situ micronucleus assay studies. Heidelberg, Germany. Ecotoxicology and Environmental Safety. 72: 1842-1848. Available: <http://www.sciencedirect. com/science/article/pii/S0147651309000906> Accessed in: 2014, set. 10.

Submetido: Abril/2015 Revisado: Outubro/2015 Aceito: Novembro/2015 